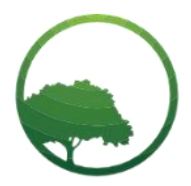

Research in Business \& Social Science

IJRBS VOL 11 NO 1 (2022) ISSN: 2147-4478

\title{
The corporate social responsibility policy in the fulfillment of facilities for workers with disability
}

\author{
I Wayan Gde Wiryawan \\ (a) Faculty of Law, Universitas Mahasaraswati Denpasar, Bali, Indonesia
}

Crossref

\author{
A R T I C L E I N F O \\ Article history: \\ Received 16 December 2021 \\ Received in rev. form 08 Feb. 2022 \\ Accepted 14 February 2022 \\ Keywords: \\ Corporate social responsibility, \\ disability, rights, labor \\ JEL Classification: \\ O15, P36
}

\begin{abstract}
A B S T R A C T
The issue of people with disabilities or people who have different abilities is now known as "diffable" (differently abled people) or now known as "disability" is a problem that on a practical level rarely gets the attention from the government, companies and community. In fact, the international community really appreciates and respects the protection of the human rights of persons with disabilities. This can be seen in the Convention on the Rights of Persons with Disabilities which is an international agreement on the protection of the rights of persons with disabilities. This international agreement was adopted on 13 December 2006 at the United Nations Headquarters in New York, and opened for signature on 30 March 2007. Indonesia itself has signed the Convention on the Rights of Persons with Disabilities on 30 March 2007 and ratified on 30 November 2011. The implication is that the state is obliged to guarantee the fulfillment of the right of people with disabilities to find work. The rights for persons with disabilities do not only end there, but also include the right to have a work area that is friendly to persons with disabilities. To fulfill these rights, companies are expected to implement corporate social responsibility policies. The corporate social responsibility is a business commitment to act ethically, operate legally and contribute to economic development along with improving the quality of life of its workforce. In this study, it will be discussed about how the formulation of corporate social responsibility in the laws and regulations in Indonesia and how to fulfill facilities for disabled workers within the framework of corporate social responsibility policies.
\end{abstract}

() 2022 by the authors. Licensee SSBFNET, Istanbul, Turkey. This article is an open access article distributed under the terms and conditions of the Creative Commons Attribution (CC BY) license (http://creativecommons.org/licenses/by/4.0/).

\section{Introduction}

The attention of people around the world has looked at people with disabilities as people who must get the same treatment as society in general, the world's attention to people with disabilities is stated in Resolution Number A/61/106 of the United Nations General Assembly regarding the Convention on the Rights of Persons with Disabilities (Convention on the Rights of Persons with Disabilities). The international community values and respects the protection of the human rights of persons with disabilities (Malik et al., 2021; Itasari \& Mangku, 2021). This can be seen in the Convention on the Rights of Persons with Disabilities which is an international agreement on the protection of the rights of persons with disabilities. This international treaty was adopted on 13 December 2006 at United Nations Headquarters in New York, and opened for signature on 30 March 2007. The international convention was signed by 82 signatories to the Convention, 44 signatories to the Optional Protocol, and 1 ratification of the Convention. The highest number of signatories to the UN Convention in history on its opening day. The Convention on the rights of persons with disabilities is the first comprehensive human rights treaty of the 21 st century and is the first human rights convention open for signature by regional integration organizations (Winzer \& Mazurek, 2017; Pertiwi \& Margaretha, 2022).

* Corresponding author.

(C) 2022 by the authors. Hosting by SSBFNET. Peer review under responsibility of Center for Strategic Studies in Business and Finance.

https://doi.org/10.20525/ijrbs.v11i1.1669

Citation: Wiryawan, I.W.G. (2022). The corporate social responsibilty policy in the fulfillment of facilities for workers with disability. International Journal of Research in Business \& Social Science (2147-4478), 11(1). 
In the Convention on the Right of Persons with Disabilities (CRPD) in 2007 in New York, United States, countries in the world agreed that people with disabilities are people who have physical, mental, intellectual, or sensory limitations in the long term (Márton et al., 2013). In addition, in interacting with the environment, there can be obstacles that make it difficult to participate fully and effectively. The emphasis on the meaning of disability in this concept is that there is a long-lasting functional impairment and causes limited participation in society. Indonesia itself has signed the Convention on the Rights of Persons with Disabilities on March 30 , 2007 and ratified on November 30, 2011. As a nation that always places recognition of human dignity as human rights, the recognition and guarantee of human rights are laid down in Article 28 I paragraph (4) of the 1945 Constitution of the Republic of Indonesia (UUD NRI 1945). Every Indonesian citizen (WNI) gets recognition in equal rights and obligations. Every citizen has the same opportunity in terms of work to earn a decent living. Every citizen in question including a person with a disability. Persons with disabilities are people who experience physical, intellectual, mental, and or sensory limitations for a long period of time; therefore, a person with a disability will experience obstacles and difficulties in interacting with the environment.

Idris (2021) define disability can manifest as physical or cognitive problems, stemming from various genetic factors, accidents, external circumstances, or advanced age. Furthermore, according to Ayuningtyas et al. (2022), disability refers to people with a lack of work capacity or the inability to work, someone who was born with a disease, or people with other conditions that are usually agerelated and can affect anyone. The definition of persons with disabilities in Indonesian laws and regulations are:

i. According to UN Resolution Number 61/106 dated December 13, 2006, persons with disabilities are individuals who are unable to provide for themselves, in whole or in part, the normal individual needs and/or social life, as a result of their disability, whether congenital or not in terms of their physical or mental abilities.

ii. In Law number 39 of 1999 concerning Human Rights, persons with disabilities are a vulnerable group of people who are entitled to more treatment and protection with regard to their specificity.

iii. In law number 11 of 2009 concerning social welfare, persons with disabilities are classified as part of a society that has a life that is not humanely appropriate and has criteria for social problems.

iv. In Law number 19 of 2011 concerning the Ratification of the Rights of Persons with Disabilities, persons with disabilities are people who have physical, mental, intellectual or sensory limitations for a long period of time who in interacting with the environment and public attitudes may encounter obstacles that make it difficult to participate fully and effectively on the basis of equal rights.

v. In Law Number 4 of 1997 concerning Persons with Disabilities, persons with disabilities are any person who has physical and/or mental disabilities that interfere with or are obstacles for them to perform properly, consisting of persons with physical disabilities, mental disabilities, and physically and mentally disabled.

vi. In Law number 8 of 2016 concerning Persons with Disabilities states that persons with disabilities are any person who experiences physical, intellectual, mental, and/or sensory limitations for a long period of time who in interacting with the environment may experience obstacles and difficulties to participate actively, fully and effectively with other citizens based on equal rights.

The limitations of a person with a disability are still a negative sigma for some people. Issues circulating in the community about people with disabilities or what are now known as "diffable" (differently abled people) have become a problem that is at a practical level; therefore, these problems get less attention from the government, companies and the community (Suharto et al., 2016; Wardana $\&$ Dewi, 2017). This is in contrast to the international world, in which the international community values and respects the protection of human rights for persons with disabilities. This can be seen in the Convention on the Rights of Persons with Disabilities (abbreviated CRPD) which is an international agreement on the protection of the rights of persons with disabilities. This international agreement was adopted on 13 December 2006 at the United Nations Headquarters in New York, and opened for signature on 30 March 2007. Indonesia itself has signed the Convention on the Rights of Persons with Disabilities on 30 March 2007 and ratified on 30 November 2011.

Limitations in the context of disability are not a barrier for a person with a disability to obtain the right to live and maintain his life, the mandate of Article 28 A of the 1945 Constitution "every person has the right to live and has the right to defend his life", the right to live is part of human rights that is non-negotiable (non-derogable rights). Recognition and guarantee of rights for persons with disabilities in Indonesian positive law has actually been regulated in Law Number 4 of 1997 concerning Persons with Disabilities. Then after Indonesia signed the Convention on the Rights of Persons with Disabilities on March 30, 2007, which was ratified by the Government of Indonesia through Law Number 19 of 2011 concerning Ratification of the Convention on the Rights of Persons with Disabilities (Convention on the Rights of Persons with Disabilities), then there was an amendment to Law Number 4 of 1997 concerning Persons with Disabilities with Law of the Republic of Indonesia Number 8 of 2016 concerning Persons with Disabilities.

Strengthening equality of rights between people with disabilities and non-disabled people has an impact on the acceptance of disabled workers/employees in a company, in which the companies are required to be socially responsible for people with disabilities and meet the facility needed by people with disabilities so that they can do their jobs as a company (Kusumastuti et al., 2014; Pertiwi et al., 2020). The companies are asked to provide job placement disclosures to persons with disabilities in certain sectors; therefore, 
they can employ persons with disabilities. Persons with disabilities are someone who has the same degree as other human beings, they have the same rights as the non-disabled people in getting a job. For this reason, a forum that can accommodate people with disabilities is needed to get suitable and humane jobs. The principle of Equitable sharing of power is put forward in an effort to respect the independence of persons with disabilities (Damayanti \& Sabiq, 2017; Kiling et al., 2019).

The Minister of Manpower of the Republic of Indonesia, Ida Fauziyah, said that currently there are 17.74 people of working age (15 years and over) who are persons with disabilities. However, only 7.8 million people entered the workforce. The participation rate of the disabled workforce is only 44 percent, while the national labor force participation rate is 69 percent," Ida said in a discussion in Jakarta, Wednesday, February 24, 2021. Based on a report from the Central Statistics Agency in February 2020, not all of the disabled workforce work., only 7.5 million are working. Meanwhile, 247,000 others are unemployed. As a result, the Open Unemployment Rate in this disability group reaches $3 \%$. The low labor force participation rate in this disability group shows several indications. had already resigned and did not dare to enter the labor market. This condition was caused by limited employment opportunities to discrimination, including the possibility of stigma against persons with disabilities. So far, more employment opportunities for persons with disabilities are available in the service sector, such as services and retail, while in the industrial sector is still minimal. One of the factors is the non-inclusive training and education for persons with disabilities.

In the International Labor Organization (ILO) in 2013, it is regulated on the management of disability. The ILO 2013 regulates the placement, recruitment process and supporting facilities for the placement of persons with disabilities to avoid the possibility of discrimination against persons with disabilities in a company. How social responsibility and the fulfilment of facilities for persons with disabilities by the company are based on the laws and regulations in Indonesia which is then accommodated in the company's policy framework. These problems become the main point in writing; therefore, the title of this scientific writing is "The Corporate Social Responsibility Policy in Fulfilling Facilities for Workers with Disabilities." Based on the title and what has been described in this introduction, it can be clearly seen that the problems that are the subject of discussion in this paper are regarding the formulation of corporate social responsibility in the laws and regulations in Indonesia and the fulfillment of facilities for disabled workers within the framework of corporate social responsibility policies.

This paper is a normative juridical scientific paper, in which the writing uses a literature study with secondary data focusing on finding references to the theory of calming the formation of corporate social responsibility for persons with disabilities. Literature review as a secondary basis comes from literary sources obtained from books, documents, scientific journals, articles that are strengthened by legal sources originating from legislation, doctrine, jurisprudence including dictionaries as scientific translators of standard words. After the library sources have been collected, an assessment is carried out in the discussion to obtain answers to the problems before drawing a conclusion as an answer to the problems raised. From these conclusions, recommendations can be made.

\section{Literature Review}

John Elkington in 1997 through his book "Cannibals with Fork, the Triple Bottom Line of Twentieth Century Business" developed the triple bottom line concept in terms of economic prosperity, environmental quality and social justice. Elkington gives the view that companies that want to be sustainable must pay attention to the "3Ps". In addition to pursuing profit, companies must also pay attention to and be involved in fulfilling the welfare of the community (people) and actively contribute in preserving the environment (planet) (Wibisono, 2007). CSR is a form of corporate responsibility to the environment for social care and environmental responsibility without neglecting the ability of the company. The implementation of this obligation must pay attention to and respect the cultural traditions of the community around the location of the business activity (Disemadi \& Prananingtyas, 2020).

Corporate Social Responsibility (CSR) strategies in line with the triple bottom line (economic, social, and environmental goals) (Velte, 2021). Chuck Williams states that: "The purpose of companies implementing CSR is to provide the best benefits to stakeholders by fulfilling economic, legal, ethical and policy responsibilities. The responsibilities include the following:

i. Economic responsibility. The main motive of the company is to make a profit. Profit is the foundation of the company. Companies must have economic added value as a prerequisite for companies to survive and develop.

ii. Legal liability. Companies must obey the law. In the process of making a profit, the company must not violate the policies and laws that have been set by the government.

iii. Ethical responsibility. The company has an obligation to carry out good, true, and fair business practices. Community norms need to be a reference for the company's organizational behavior. The key word: be ethical.

iv. Philanthropic responsibilities. In addition to the company must earn profits, obey the law and behave ethically, companies are required to be able to make a contribution that can be felt directly by the community. The goal is to improve the quality of life for all. The owners and employees who work in the company have a dual responsibility, namely to the company and to the public which is now known as non-fiduciary responsibility" (Napitupulu, 2001).

Persons with disabilities are a diverse group of people, including persons with disabilities who have physical disabilities, mental disabilities or a combination of physical and mental disabilities. The condition of persons with disabilities may have little impact on their ability to participate in society, or even have a large impact that requires support and assistance from others (International Labor 
Officer, 2006). Law Number 8 of 2016 concerning Persons with Disabilities defines that Persons with disabilities are any person who experiences physical, intellectual, mental, and/or sensory limitations for a long period of time who in interacting with the environment may experience obstacles and difficulties to participate fully and effectively with the environment. There is also a negative stigma from society regarding persons with disabilities as a family disgrace or curse, thus hiding their existence and giving discriminatory treatment. The discrimination experienced by persons with disabilities include:

i. Attitude discrimination occurs when persons with disabilities are socially excluded due to a feeling of discomfort and neglect of the general public (not persons with disabilities). This form of discrimination can be in the form of negative language or expressions by the general public that demean persons with disabilities. Another form that may occur is that they are excluded from the community because usually people still underestimate the ability of people with disabilities to achieve something, including doing a job.

ii. Environmental discrimination occurs when public services, buildings and transportation are not designed by considering access for people with disabilities.

iii. Institutional discrimination occurs when existing laws clearly discriminate against or obscure the rights of persons with disabilities, making them second-class people without the right to vote, own land, go to school, have a family, and have children (Australia Indonesia Partnership of Justice, 2014).

The World Health Organization (WHO) states disabilities is a condition where a person experiences limitations due to a physical disability, making it difficult to access all public facilities and infrastructure (Rahmayuni et al., 2021). In protecting people with disabilities from various forms of discrimination, especially discrimination in finding work and in the work environment, various policies within the framework of corporate social responsibility are needed.

\section{Corporate social responsibility towards workers with disabilities and implications}

Human Resources is an important organ in the company. In its implementation, human resources have 9 scope strategies including: work, planning, recruitment and selection, performance management, human resource development, reward management, employee relations, employee downsizing and orderliness (Soelistijo, 2013; Muda, 2014; Sembiring, 2016; Aryanto et al., 2015). The nine scopes of these strategies have a relationship with each other that will build harmony within a company; therefore, the company can run well to achieve the goals of the company itself.

The source of human resources is how the ability of humans is needed based on the position, type of work, workload, ability of workers and competitiveness between workers. These points are also affected by the physical condition of the workers, even though human rights place humans as equal before the law and government, still the paradigm of the quality and quantity of performance of a person with a disability and a non-disabled person cannot be placed in an equal position in the certain sectors. People with disabilities have fundamental rights like humans in general. People with disabilities receive special treatment which is intended as an effort to protect against vulnerability to various human rights violations. Law Number 19 of 2011 concerning the Convention on the Rights of Persons with Disabilities, Article 1 states that the purpose of this convention is to promote, protect and ensure the full and equal enjoyment of all human rights and fundamental freedoms by all persons with disabilities, and to promote respect for their inherent dignity.

The Minister of Manpower explained that the total number of people with disabilities in Indonesia is around 21 million people. Of this amount, approximately 11 million people are included in the age of the workforce and 96.31 percent of them have worked in various sectors of work. The informal sector is the field that most people with disabilities are interested in. This proves that people with disabilities have skills and competencies in life even though they have physical limitations. People with disabilities are part of Indonesian society, as Indonesian citizens and citizens with disabilities have equal rights, obligations, opportunities and roles in all aspects of life. In the business world, the existence of Corporate Social Responsibility (CSR) is a form of commitment from the company to run its business legally and contribute to improving the shared economy to improve the standard of living and quality of life of the employees.

As a form of corporate social responsibility towards workers with disabilities, companies are required to establish a Corporate Social Responsibility (CSR) management. CSR is as a form of proactive, structured and sustainable company efforts in realizing business operations that are socially acceptable and environmentally friendly in order to achieve financial success. Some of the laws and regulations in Indonesia that regulate CSR are as follows:

i. Law Number 40 of 2007 concerning Limited Liability Companies; The regulation on CSR can be seen in Article 74, in which the Corporate Social Responsibility is only required for companies that carry out business activities in and/or related to Natural Resources (SDA).

ii. Law Number 25 of 2007 concerning Investment; The regulation of Corporate Social Responsibility (CSR) in the Investment Law is contained in Article 15 letter b, Article 16, and Article 34.

iii. Law Number 21 of 2014 concerning Geothermal; In Article 65 paragraph (2) letter b "In the implementation of Geothermal management, the community has the right to: obtain benefits from Geothermal exploitation activities through the company's obligation to fulfill corporate social responsibility and/or development of the surrounding community." 
iv. Law Number 4 of 2009 concerning Mineral and Coal Mining (Minerba Law);

v. Law Number 22 of 2001 concerning Oil and Gas (Law on Oil and Gas);

vi. Law Number 13 of 2011 concerning Handling the Poor;

vii. Law Number 32 of 2009 concerning Environmental Protection and Management;

viii. Government Regulation Number 47 of 2012 concerning Social and Environmental Responsibility of Limited Liability Companies;

ix. Government Regulation Number 23 of 2010 concerning the Implementation of Mineral and Coal Mining Business Activities;

x. Regulation of the Minister of State for State-Owned Enterprises No. Per05/MBU/2007 of 2007 concerning the Partnership Program of State-Owned Enterprises with Small Businesses and the Community Development Program as last amended by Regulation of the Minister of State-Owned Enterprises No. PER-08/MBU/2013 of 2013 concerning the Fourth Amendment to the Regulation of the State Minister for State-Owned Enterprises No. Per-05/MBU/2007 of 2007 concerning the Partnership Program of State-Owned Enterprises with Small Businesses and the Community Development Program.

Corporate Social Responsibility legally as regulated in Chapter V, Article 74 of Law Number 40 of 2007 concerning Limited Liability Companies is a form of corporate social responsibility towards the environment and its existence in carrying out business activities. The Corporate Social Responsibility is a form of commitment from the company to establish cooperation both directly and indirectly as a form of the company's commitment in improving the welfare of the community by providing space for the community to contribute to the company's resources. In Corporate Social Responsibility management, the company will provide a portion for people with disabilities in certain sectors or management that can be done by employees with disabilities. In Article 53 of Law Number 8 of 2016 concerning Persons with Disabilities, it is regulated about providing employment opportunities for persons with disabilities in the private sector by $1 \%$ and in the government sector by $2 \%$. There are also several legal arrangements regarding employment opportunities for persons with disabilities which can be seen in as follow:

i. The 1945 Constitution of the Republic of Indonesia Article 28/I paragraph 2 concerning the right of a person to receive free treatment from discrimination;

ii. The Law of 1997 No. 4 concerning Persons with Disabilities which emphasizes the fulfillment of the rights of persons with disabilities in employment;

iii. The Law No. 13 of 2002 concerning Manpower, concerning equal opportunities for every worker without discrimination;

iv. The Law of the Republic of Indonesia Number 19 of 2011 concerning the Ratification of the Convention on the Rights of Persons with Disabilities.

With the existence of these legal rules, persons with disabilities have a strong legal basis in claiming their rights to obtain decent work opportunities and are free from all forms of discrimination. Based on data obtained from the Government of Western Australia Department of Communities Disability Services, persons with disabilities have positive attitudes and behaviors in the world of work. From the aspect of productivity. A person with a disability has a tendency to have high productivity behind their limitations as long as the work given to him is in accordance with his abilities, type of disability, facilities and supporting tools that are appropriate to support the performance of the person with disability. From the aspect of work consistency. A person with a disability can do their job consistently because their disability tendency makes them feel more comfortable at work with a commitment to complete more work than their non-disabled counterparts. From the financing side. In terms of financing, the recruitment of a person with a disability requires a lower cost when compared to non-disabled workers, because disabled workers can only do limited work on their abilities which cannot be equated with non-disabled workers. From the security side. The high precautionary attitude of persons with disabilities reduces the possibility of work accidents for persons with disabilities, in which they will work very carefully and consistently. From the aspect of building a working relationship. Persons with disabilities have good morals and loyalty so that they can build harmonious working relationships within the company environment.

\section{The formulation of corporate social responsibility in the laws and regulations in Indonesia}

The implementation of corporate social responsibility in Indonesia is more a form of willingness from the company; therefore, the implementation is very dependent on the commitment and ethical norms of the company to the social conditions of the surrounding environment, while in developed countries and developing countries corporate social responsibility is a must for companies with government sanctions and supervision. The Indonesian government is gradually forming legal formulations that can be enforced in Indonesia in laws and regulations related to corporate social responsibility. There are several existing laws and regulations in Indonesia related to corporate social responsibility:

\section{Corporate social responsibility in Law Number 25 Year 2007 concerning Investment (Investment Law)}

The Law Number 25 of 2007 concerning Investment was passed on April 26, 2007, this law initiates the obligation of corporate social responsibility in the Indonesian legal system. The definition of corporate social responsibility can be found in the explanation of article 15 letter b, corporate social responsibility is the responsibility inherent in every investment company to continue creating harmonious, balanced, and in accordance with the environment, values, norms, and culture of the local community. In the Investment Law, the regulation on corporate social responsibility can be seen in the provisions of Article 15 letter b, which states that: Every investment has the obligation to: 


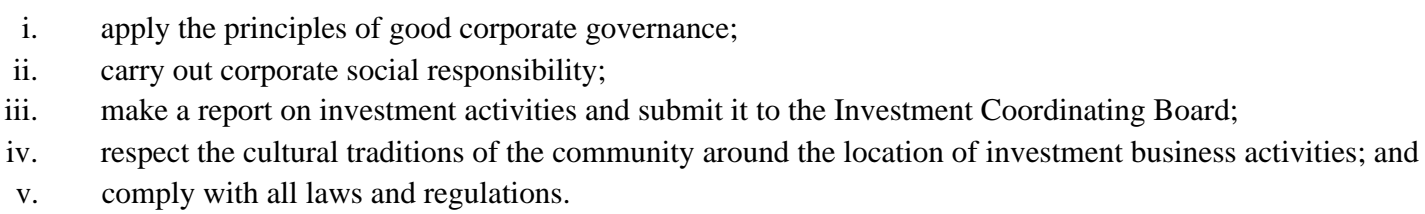

Sanctions to investment entrepreneurs for violations of corporate social responsibility obligations are regulated in Article 34 which sanctions that:

A business entity or individual business as referred to in Article 5 which does not fulfill the obligations as referred to in Article 15 may be subject to administrative sanctions in the form of:

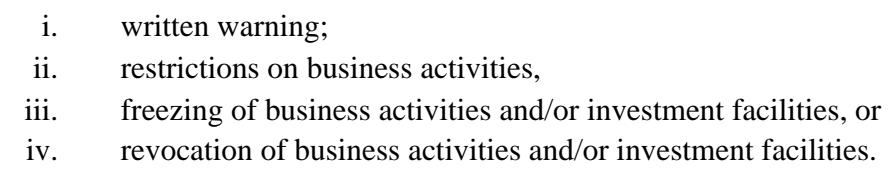

I. The administrative sanctions as referred to in paragraph (1) shall be imposed by the authorized agency or institution in accordance with the provisions of the legislation.

II. In addition to being subject to administrative sanctions, business entities or individual businesses may be subject to other sanctions in accordance with the provisions of laws and regulations.

The investment law regulates sanctions for violations of corporate social responsibility, but it does not mention the forms of corporate social responsibility violations from companies that can be subject to sanctions.

\section{Corporate social responsibility in Law Number 40 of 2007 concerning Limited Liability Companies (Incorporated Company Law)}

Article 1 point 3 of the Incorporated Company Law states that corporate social and environmental responsibility is an individual's commitment to participate in sustainable economic development in order to improve the quality of life and the environment that is beneficial, both for the company itself, the local community, and society in general.

Article 74 states that:

i. Companies that carry out their business activities in the field of and or related to natural resources are obliged to carry out social and environmental responsibilities.

ii. The social and environmental responsibility as referred to in paragraph (1) is the company's obligation which is budgeted and calculated as the company's expense whose implementation is carried out with due regard to propriety and fairness.

iii. Companies that do not carry out the obligations as referred to in paragraph (1) are subject to sanctions in accordance with the provisions of the laws and regulations.

Further provisions regarding social and environmental responsibility are regulated by government regulations.

Corporate social responsibility as referred to in the Limited Liability Company law is only limited to companies that carry out their business activities in the business sector related to the utilization of natural resources. The company must budget for Corporate Social Responsibility as a company expense which is carried out with due regard to propriety and fairness.

\section{Corporate social responsibility in Law Number 23 of 1997 concerning Environmental Management}

The right to the environment is a human right that has been recognized by the United Nations. Article 6 paragraph (2) of the Environmental Management Law emphasizes the obligation for business actors to provide true and accurate information regarding environmental management. Several articles in the environmental management law related to Corporate social responsibility activities are Article 5 paragraph (1), (2) and paragraph (3), Article 6 paragraph (1) and (2), and Article 7 paragraph (1) and (2).

\section{Corporate social responsibility in Law Number 4 Year 2009 concerning Mineral and Coal.}

Article 95 letter (d) of the Minerba Law states that holders of Mining Business Permits (IUP) and Special Mining Business Permits (IUPK) are required to carry out development and empowerment of local communities. If it is interpreted in the article, it requires that mining entrepreneurs have social responsibility to the community around the mining business area. The form of social responsibility of mining entrepreneurs to the community is contained in Article 78 letter (j), including:

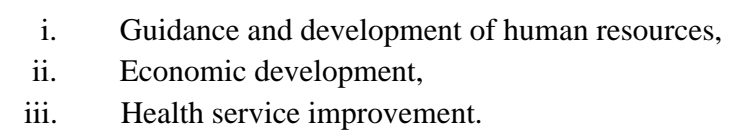

Corporate social responsibility in Law Number 22 of 2001 concerning Oil and Gas.

In the oil and gas law there are two articles that regulate corporate social responsibility, namely: 
i. Article 11 paragraph (3); it is stated that upstream business activities carried out by a Business Entity or Permanent Establishment based on a Cooperation Contract with the Implementing Body must contain basic provisions, one of which is provisions regarding the development of surrounding communities and guarantees of the rights of indigenous peoples.

ii. Article 40 paragraph (5); Stating that the Business Entity or Permanent Establishment that carries out Oil and Gas business activities (upstream business activities and downstream business activities) is responsible for developing the environment and local communities.

Based on the formulation of corporate social responsibility, there are two weaknesses regarding the regulation of Corporate social responsibility in Indonesian laws and regulations, these weaknesses are as follows:

\section{Regarding company restrictions}

In the limited liability company law, Article 74 companies that are required to carry out Corporate Social Responsibility are companies whose business activities are in the field of business related to natural resources, so that other companies whose business activities are outside of business activities related to natural resources do not have the obligation to carry out Corporate social responsibility.

\section{Regarding the weak implementation of sanctions}

In the Limited Liability Company law regarding the regulation of sanctions, it is made in the form of delegation of sanctions with the applicable laws and regulations, the meaning of the applicable laws and regulations has biased assumptions which creates ambiguity and weakens the rules themselves.

Article 34 of the investment law states that if investors do not carry out their obligations to carry out corporate social responsibility, then based on the provisions of the investment law, they can be subject to sanctions in the form of administrative sanctions up to sanctions for revocation of business activity permits. Meanwhile, the law does not stipulate regulations and assessments of business actions which include violations of corporate social responsibility so that sanctions can be imposed. The sanctions are in the form of repatoir condemnatoir administrative sanctions, meaning that the procedure for implementing administrative sanctions for violations of the law is carried out by administrative officials in the realm of state administration. Decisions from state administrative officials have a final, individual and concrete nature called beschiking.

The formulation of corporate social responsibility in the laws and regulations in Indonesia, has been regulated in several of the laws and regulations mentioned above but still contains a biased meaning because there are no affirmations that become references in determining sanctions.

\section{Fulfillment of facilities for workers with disabilities within the framework of corporate social responsibility policies}

Everyone wants to be a productive member of society, including the disabled. The Republic of Indonesia, which is based on Pancasila and the 1945 Constitution of the Republic of Indonesia, greatly respects and upholds human dignity. Human Rights (HAM) as basic rights that are inherently inherent in human beings are universal, and need to be protected, respected, and defended, including the human rights of people with disabilities. Therefore, to prevent the more vulnerable people with disabilities live in vulnerable, backward, and poor conditions because there are still restrictions, obstacles, difficulties, and the reduction or elimination of their rights, through Law Number 13 of 2003 concerning Manpower and Law Number 8 In 2016 concerning Persons with Disabilities, the state regulates the rights of people with disabilities to enter the labor market.

Article 1 point 5 Regulation of the Minister of Public Works Number 30/PRT/M/2006 concerning Technical Guidelines for Facilities and Accessibility in Buildings and the Environment, what is meant by persons with disabilities/disability is any person who has physical and/or mental weakness/inability, who can interfere with or be an obstacle for him to carry out normal life and livelihood activities. In the Convention on The Rights of Persons with Disabilities, persons with disabilities include those who have long-term physical, mental, intellectual or sensory limitations. According to WHO, people with disabilities are divided into 3, namely: impairment, abnormalities in psychological or anatomical structural or functional abnormalities. Disability, an inability to carry out a certain activity as a normal person due to an impairment condition. Handicap, difficulties in personal, family and community life both in the socio-economic and psychological fields experienced by a person due to the abnormality.

Persons with disabilities as regulated in Law Number 8 of 2016 concerning Persons with Disabilities are divided into four categories, namely persons with physical disabilities, people with intellectual disabilities, people with mental disabilities, and Persons with sensory disabilities. Of the four types of people with disabilities, people with certain physical disabilities are more likely to get job opportunities. The corporate social responsibility policy has obligations, including to carry out protection of work facilities for workers with physical disabilities. The physical disabilities include several types of disabilities, namely:

i. Physically disabled. Physically disabled are individuals who have movement disorders caused by neuro-mascular and bone structure disorders caused by congenital abnormalities, due to disease, due to accidents.

ii. Blind. Blindness is a disability where a person has obstacles in vision, blind people can be reclassified into two, namely total blindness (blind), and low vision.

iii. Deaf. Deafness as a form of disability in the form of hearing impairment, whether permanent or not. 
iv. Speech impaired. The speech impaired are people who experience disorder verbally in expressing thoughts so that it is not easy for others to understand.

Employers must provide work facilities that are in accordance with the degree of disability of the worker. The right to get a job is the right of every person which is the embodiment of human rights in terms of fulfilling their life needs. The company's corporate social responsibility in its obligation to provide protection to workers with disabilities relates to the provisions of Article 1 paragraph (31) of Law Number 13 of 2003 concerning employment, in which the company guarantees the welfare of workers by fulfilling physical and spiritual needs, both internally and externally of the work relationship, which can directly or indirectly increase work productivity in a comfortable and healthy work environment.

The formulation of the article requires companies to provide supporting facilities for disabled workers, based on the disability needs of these workers. Facilities for disabled workers are tools for people with disabilities, article 1 paragraph (10) of the Law on Persons with Disabilities defines assistive devices as objects that function to assist the independence of persons with disabilities to carry out daily activities. Article 1 point 6 of Law Number 8 of 2016, fulfillment is an effort made to fulfill, implement, and realize the rights of persons with disabilities. The company's corporate social responsibility obligations in carrying out the fulfillment of physical facilities for persons with disabilities have been regulated in Article 67 paragraph (1) of Law Number 13 of 2003 concerning Manpower. It is stated in the article that "entrepreneurs who employ workers with disabilities are obliged to provide protection according to the type and degree of disability suffered by the worker". The degree of record of a person with a disability greatly determines the supporting facilities needed and must be prepared by the company. The degree of disability of a person with a disability in Article 7 of the Regulation of the Minister of Health of the Republic of Indonesia number: 104/MENKES/PER/II/1999 concerning Medical Rehabilitation regulates that the disability of a person with a disability is assessed based on the person's ability to carry out daily activities which can be grouped into 6 degrees of disability, namely:

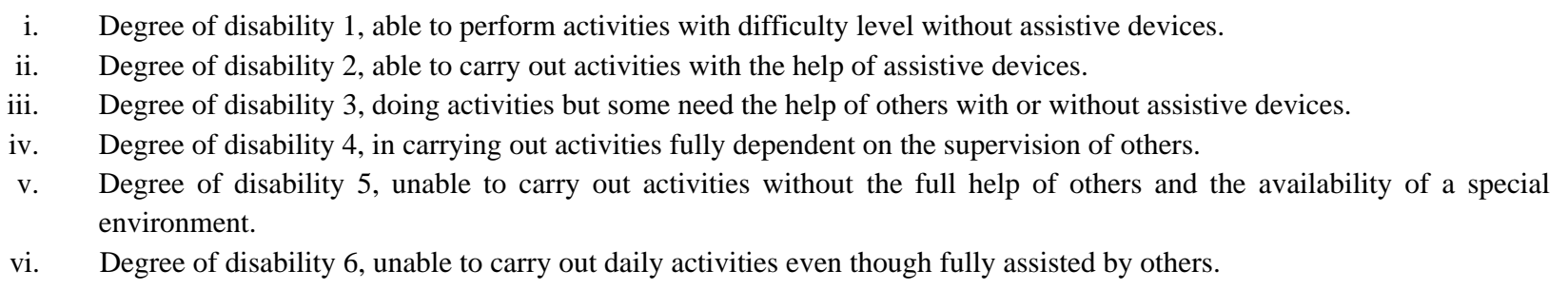

According to the ILO, worldwide, employment discrimination prevents many women and men, including persons with disabilities, from participating in the labor market and reaching their full potential. Convention No. 111 on discrimination is one of the main ILO conventions. Women and men with disabilities can and want to be productive members of society. In developed and developing countries, promoting a more inclusive society and greater employment opportunities for persons with disabilities requires better access to basic education, vocational training that is relevant to the needs of the labor market and jobs that match skills, interests and interests. their abilities with the necessary adaptations. Many communities also recognize the need to break down other barriersmaking the physical environment more accessible, providing information in various forms, and challenging attitudes and erroneous assumptions about people with disabilities. There are several steps forward proposed by the ILO to address the issue of the right to work for persons with disabilities in Indonesia. Productive and decent work enables persons with disabilities to realize their aspirations, improve their living conditions and participate more actively in society. The ILO ensures a disability perspective in all aspects of employment policies and regulations, the effective implementation and enforcement of disability laws and policies as well as providing equal employment opportunities and training are, among other things, factors that contribute to poverty reduction and to the social inclusion of persons with disabilities and economy in Indonesia.

Technically, the objectives of the facilities for disabled workers provided by employers as regulated in the company's corporate social responsibility are as follows:

i. Availability of types of work for persons with disabilities. Gary. L. Albrecht said that access to job opportunities through the types of work provided for people with disabilities can access job opportunities on a par with others, so that information on job opportunities is provided in an accessible way, job fairs and recruitment are also carried out in an accessible way, including through the online media considering that many people with disabilities have mobility difficulties.

ii. Facilitation facilities for persons with disabilities to reach physical and non-physical work or the affordability of persons with disabilities in accessing work physically and non-physically. Physical accessibility is a facility that can literally be seen, held and felt, while non-physical facilities are related to how information, communication and technology can be utilized and understood by persons with disabilities. Non-physical accessibility to disabled workers is carried out by:

a. In producing and disseminating information, consideration should be given to whether the information can be easily understood by persons with disabilities.

b. In making information that is friendly to disability, it is made in certain forms and formats such as raised font for blind people.

c. In providing communication support services that aim to make people with disabilities better understand the information available, such as using sign language for people who are deaf or providing hearing aids. 
iii. The ease of use of work facilities for persons with disabilities. Some forms of public facilities that can be provided by employers for workers with disabilities are:

a. To facilitate the recruitment of persons with disabilities and job protection for workers who become disabled, employers need to take steps to increase the accessibility of the workplace for persons with disabilities in various forms. This includes providing a gate/entrance to and ease of movement in the workplace as well as the ease of use of restrooms and bathrooms.

b. Accessibility includes signs/writings (that the facility is being used), manuals, workplace instructions and electronic information. such accessibility is intended for those with visual impairments, and especially for those with intellectual disabilities.

c. Accessibility for the hard of hearing includes access to information that is often conveyed by voice - such as the sound of a bell, fire alarm, whistle or siren. Such facilities need to be reviewed and supplemented, if necessary, by alternative means such as flashing lights.

d. Planning for dealing with emergencies should ensure that persons with disabilities can safely and effectively leave the workplace to a safe area.

A company must be able to provide job facilities. The facilities provided must be friendly to people with disabilities in order to make the work easier. These results are in satisfying work and do not make the company lose money.

The ease of providing opportunities for persons with disabilities to develop careers in work. Persons with disabilities have the right to choose the work they want, including through self-employment, developing partnerships and starting their own business. All of this needs to be balanced with the provision of skills to develop the quality and creativity of the products produced to suit market demands, including other entrepreneurial skills. Another thing that is no less important is the easy access to the capital for persons with disabilities.

The absence of discrimination in the workplace can be indicated by, among others, the absence of termination of employment on the grounds of disability; accessibility (physical or non-physical) in place; a work environment that is safe and comfortable and free from all forms of harassment; an equal pay system in which disabled employees are not paid less than non-disabled employees for the same position; opportunities to access technical expertise, continuing skills and career development programs.

\section{Conclusions}

Corporate social responsibility is a company's long-term commitment to improving the quality of the company's environment both internally and externally. The company's corporate social responsibility is applied in activities that touch social aspects, education, skills training and economic aspects. The formulation of corporate social responsibility in Indonesia is strictly regulated in Law Number 25 of 2007 concerning Investment, Law Number 40 of 2007 concerning Limited Liability Companies, Law Number 23 of 1997 concerning Environmental Management, Law Number 4 of 20072009 concerning Minerals and Coal and Law Number 22 Year 2001 concerning Oil and Gas. In the implementation of corporate social responsibility for workers with disabilities, the employers are required to provide supporting facilities for disabled workers, fulfillment of facilities for workers with disabilities. Within the framework of corporate social responsibility, the policies carried out by employers are to provide types of work that are in accordance with the abilities of disabled workers, provide facilities for people with disabilities that are easily accessible to work with disabilities both physically and non-physically, provide facilities for people with disabilities to get opportunities to develop careers with the same opportunities as other non-disabled workers.

Indonesia already has laws and regulations that oblige entrepreneurs in corporate social responsibility to ensure continuity and provide equal employment opportunities to persons with disabilities based on the concept of human rights equality. It only applies to entrepreneurs who carry out business activities in sectors that are in direct contact with nature; therefore, the government should start adopting western country laws that have required corporate social responsibility to all business sectors to be able to absorb disabled workers in more capacities, with the broader placements and types of work. This action will greatly assist the government in poverty alleviation and human empowerment programs based on equal human rights. Talking about the fulfillment of facilities for disabled workers, specific and detailed rules regarding the form, type and standard of facilities for disabled workers cannot be found in existing laws and regulations; therefore, the company will formulate its own types and forms of facilities used in the company. It will be very helpful for the employers if it has been determined by the state in a legal regulation regarding the type, form and standard of assistance facilities for disabled workers.

Author Contributions: Conceptualization, IWGW.; Methodology, IWGW.; Data Collection, IWGW.; Formal Analysis, IWGW.; Writing—Original Draft Preparation, IWGW.; Writing-Review And Editing, IWGW.; All authors have read and agreed to the published the final version of the manuscript.

Institutional Review Board Statement: Ethical review and approval were waived for this study, due to that the research does not deal with vulnerable groups or sensitive issues.

Data Availability Statement: The data presented in this study are available on request from the corresponding author. The data are not publicly available due to privacy.

Conflicts of Interest: The authors declare no conflict of interest. 


\section{References}

Aryanto, R., Fontana, A., \& Afiff, A. Z. (2015). Strategic human resource management, innovation capability and performance: An empirical study in Indonesia software industry. Procedia-Social and Behavioral Sciences, 211, 874-879.

Australia Indonesia Partnership of Justice (AIPJ). (2014). Panduan Advokasi Hak Asasi Manusia Bagi Organisasi Penyandang Disabilitas. Jakarta: Australia Aid, Jakarta.

Ayuningtyas, D., Rachmawati, R., Larasanti, A., Margaretha, C., Hasibuan, S. U., \& Ayuni, Q. (2022). The Law on Persons with Disabilities: How Far Have We Gone? (Case Study In Indonesia). Journal of Legal, Ethical and Regulatory Issues, 25(1), 119.

Damayanti, M., \& Sabiq, F. (2017). Implementation of public facilities and disability treatments: a comparison between indonesia and malaysia. Advances in Social Science, Education and Humanities Research, 153(1), 11-15.

Disemadi, H. S., \& Prananingtyas, P. (2020). Kebijakan Corporate Social Responsibility (CSR) sebagai Strategi Hukum dalam Pemberdayaan Masyarakat di Indonesia. Jurnal Wawasan Yuridika, 4(1), 1-16.

Idris, M. F. (2021). Access to Justice for Disability in the Perspective of John Rawls Theory (Case of Demak Regecy Indonesia). Journal of Law and Legal Reform, 2(3), 391-400.

International Labour Officer. (2006). Kaidah ILO tentang Pengolahan Penyandang Cacat di Tempat Kerja. Jakarta: ILO Publication.

Itasari, E. R., \& Mangku, D. G. S. (2021). Implementation of Convention on The Rights of Persons with Disabilities in Providing Legal Protection for Persons with Disabilities in Indonesia. Jurnal Ilmiah Pendidikan Pancasila dan Kewarganegaraan, 6(1), 129-137.

Kiling, I., Due, C., Li, D., \& Turnbull, D. (2019). Perceptions of disability, environmental risk factors and available services among local leaders and parents of young children with disabilities in West Timor, Indonesia. Disability and Rehabilitation, 41(20), 2421-2432.

Kusumastuti, P., Pradanasari, R., \& Ratnawati, A. (2014). The problems of people with disability in Indonesia and what is being learned from the World Report on Disability. American journal of physical medicine \& rehabilitation, 93(1), S63-S67.

Malik, F., Abduladjid, S., Mangku, D. G. S., Yuliartini, N. P. R., Wirawan, I. G. M. A. S., \& Mahendra, P. R. A. (2021). Legal Protection for People with Disabilities in the Perspective of Human Rights in Indonesia. International Journal of Criminology and Sociology, 10, 538-547.

Márton, S. M., Polk, G., \& Fiala, D. R. C. (2013). Convention on the Rights of Persons with Disabilities. USA: United Nations.

Muda, I. (2014). Human Resources Development and Performance of Government Provincial Employees: A Study in North Sumatera, Indonesia. Journal of Economics and Behavioral Studies, 6(2), 152-162.

Rahmayuni, Y., Usman, J., \& Rahim, S. (2021). Formulasi Kebijakan Peraturan Daerah Bagi Penyandang Disabilitas Di Kabupaten Bulukumba. Kajian Ilmiah Mahasiswa Administrasi Publik (KIMAP), 2(2), 532-545.

Sembiring, R. (2016). Impact of human resources' knowledge and skills on SMEs' in Medan City, Indonesia. International Journal of Management, Economics and Social Sciences, 5(3).

Soelistijo, U. W. (2013). The influence of geopolitics and strategical factors upon the development of natural and human resources in Indonesia. Social Sciences, 2(6), 200-211.

Suharto, S., Kuipers, P., \& Dorsett, P. (2016). Disability terminology and the emergence of 'diffability'in Indonesia. Disability \& society, 31(5), 693-712.

Pertiwi, P., Llewellyn, G., \& Villeneuve, M. (2020). Disability representation in Indonesian disaster risk reduction regulatory frameworks. International journal of disaster risk reduction, 45, 101454.

Pertiwi, P. P., \& Margaretha, M. (2022). Localising Disability-Inclusive Disaster Response in Indonesia. In Post-Disaster Governance in Southeast Asia (pp. 201-223). Springer, Singapore.

Velte, P. (2021). Meta-analyses on corporate social responsibility (CSR): a literature review. Management Review Quarterly, 1-49.

Wardana, A., \& Dewi, N. P. Y. P. (2017). Moving away from paternalism: the new law on disability in Indonesia. Asia-Pacific Journal on Human Rights and the Law, 18(2), 172-195.

Wibisono, Y. (2007). Membedah Konsep \& Aplikasi CSR (Corporate Social Responsibility). Jakarta: PT Gramedia.

Winzer, M., \& Mazurek, K. (2017). The convention on the rights of persons with disabilities. United Kingdom: The Wiley Handbook of diversity in special education.

Publisher's Note: SSBFNET stays neutral with regard to jurisdictional claims in published maps and institutional affiliations.

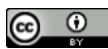

(C) 2022 by the authors. Licensee SSBFNET, Istanbul, Turkey. This article is an open access article distributed under the terms and conditions of the Creative Commons Attribution (CC BY) license (http://creativecommons.org/licenses/by/4.0/).

International Journal of Research in Business and Social Science (2147-4478) by SSBFNET is licensed under a Creative Commons Attribution 4.0 International License. 